Ambient Science, 2020: Vol. 07(Sp1); 39-40

DOI:10.21276/ambi.2020.07.sp1.nc02

\title{
Satisfaction Levels of the Sports Sciences Students Participating in Online Courses in SummerSchool
}

\section{Ahmet Șirinkan}

University of Atatürk, Faculty of Sports Sciences, Department of Recreation, Erzurum/Turkiye
Study Area: Erzurum, Turkey

Coordinated: $39^{\circ} 54^{\prime} 31^{\prime \prime} \mathrm{N} 41^{\circ} 16^{\prime} 37^{\prime \prime} \mathrm{E}$

Key words: E-learning, Onling teaching.

\section{Introduction:}

Different from traditional education system, your child is at the center of online education system. Rather than everything included and taught during lessons, your children can follow lessons independent from time and place at online education system. Again, different from traditional education system, your child can repeat lessons with e-education whenever he desires. This attribute of eeducation system which differentiates it from traditional education system, also solves the problem of cannot learn the topic.

Included video solutions of complicated problems and questions at e-education system shows the importance of E-education for your child's future and success one more time. Your child learns faster the relation between theoretical and practical with problem solving videos and meanwhile it also provides taught to be implemented in a fasterway.

E-education system includes traditional education materials while having visual and auditory contents. For example, with the help of rich visual and auditory content's help it makes learning more attractive, enjoyable, and understandable for your child and buffers your child's learning level.

Today as parents you cannot be with your child at the lessons, you cannot join to classes but with the help of strong assessment and evaluation system of e-education you can take detailed reports about your child's educational status and guide him.

Benefits of online education: online education has various advantages such as giving the opportunity of arranging study time by one's self. You might want to make carrier change, extra education, or just want to learn something new. On the other hand nowadays intensive conditions make nearly impossible to follow a regular program to do this but online education is a splendid opportunity for those who wants this. Generally;

$\checkmark$ Reaches the large masses and gives opportunity to take education for everyone.

४ Supports lifelong education.
- Suppress regional and geographical obstacles since it is independent from timeand place.

- Gives opportunity to every single learner to learn at their learning speed.

- It is an economic alternative to use for in service training.

- Gives opportunity to teach a lesson with rich, developed and interactive devices.

- It gives full access to learning place and lesson materials.

- Gives common class content with the economic and reusable class materials.

-It is a system that submits various communication technologies to education service.

- It removes expenses occurs in traditional educational such as transportation, shelter and nutrition.

- It creates an interactive and dynamic learning process with instructors.

\section{Methodology:}

A total of 225 students (155 male+70 female) from Atatürk University, 4 departments of Faculty of Sports Science (Physical Education and Sports Teaching, Sports Coaching, Sports Management and Recreation Department), and students who are attending to summer school from various faculties and universities have attended to study. Firstly students have reached online. The online interview forms are 10 questions forms which have transformed from a question bank which has 40 questions in it by the opinions and decisions of faculty members of Sports Sciences Faculty.

The study have occurred with usage of 10 questioned interview form as online. Answers for questions about exam applications of online courses, lecture watching conditions, lecturing of academic members and students' course following conditions etc. was try to be understood.

Online Interview format with, Yes/ No/ Undecided options.

S.1 Didyouchoosethisschoolwillingly?

S.2 Didyouchooseyourdepartmentwillingly?

S. 3 Is thereanydiff iculties in teachinglessons, homework or research due to pandemic?

S.4 Areyousatisfiedwithonlinelessons?

S. 5 Areyousatisfiedwithlecturing of academicmembers?

S. 6 Arethelecturewatchingconditions of studentsenough?

S.7 Arecourseequipmentsenough?

S.8 Areresourcessuch as classesandgymsenough? 
S. 9 Can youreachwrittensourcesforcourseeasily?

S. 10 Areyouhappyaboutexamapplications?

\section{Results and Evaluations:}

DAs the conclusion of study, most of the students (87\%) chose this school and their departments willingly, having internet issues about lectures watching (65\%). They were unwilling to attend online classes $(70 \%)$, having negativities at internet and class displays ( $55 \%)$, there was no contribution to their knowledge by mid-term exams as homework $(75 \%)$, there were conflicts between some lessons and final exams (65\%) and they cannot attend to exams ( $45 \%)$ were issued.

They also issued that lecturing of academic members is fine $(75 \%)$, having no problems about resources such as classes, gyms and class related resources $(80 \%)$. As positive impacts they had mentioned online exams were carrying less risk for their health, prevents negativities about transportation, nutrition and sheltering.

In a study done at 2016 about satisfaction research, from Turkey Universities Satisfaction Research (TÜMA) some points to draw attention; Universities cannot response to students' expectations. At universities, there was no focus about if the teaching occurred in classes or not. There was no understanding to be sure about whether students learnt the lectures or not, focus of academic culture was teaching the lessons and making examination for supervising. (Engin \& Cemil, 2017).
At another study about satisfaction, students of Hacettepe University cared more about aspect services of "academic services and relations" but they were not satisfied about the quality of services. Students of Hacettepe University cared more about aspect services of "academic consulting and guidance" yet still they are not satisf ied about the quality. (Ekinci \& Burgaz, 2007).

Another study to education faculty students were done which showed that future teachers candidate are generally at "low" level of satisfaction to education faculty. With this a conclusion reached about in the subdimensions such as academic members, managerial services, resources, computer opportunities are also at "low" level of satisfaction.

\section{References:}

Engin K. \& Cemil .Y. (2017): Türkiye Üniversite Memnuniyet Arastirmasi [TÜMA-2017]: Report Summary.

Ekinci C.E. \& Berrin, B.B. (2007): Hacettepe Üniversitesi Ögrencilerin in Bazi Akademik Hizmetlere Iliskin Beklenti Ve Memnuniyet Düzeyleri. Hacettepe Üniversitesi Egitim Fakültesi Dergisi.33:120-134.

Sümen, Ö.Ö. \& Çaglayan, K.T., (2013): Ögretmen Adaylarinin Egitim Fakültesinden Memnuniyet Düzeyleri VeHayal Ettikleri Egitim, XII. National Grade Teacher Training Symposium, Samsun. 